\title{
DETERMINANTS AND SIGNIFICANCE OF UNIVERSITY-BUSINESS COOPERATION IN THE REGIONAL CONTEXT
}

\author{
Monika JAKUBIAK $^{1 *}$, Marta CHOLEWA-WIKTOR ${ }^{2}$ \\ ${ }^{1}$ Maria Curie-Sklodowska University, Lublin; monika.jakubiak@umcs.pl, ORCID: 0000-0002-0033-3142 \\ ${ }^{2}$ Lublin University of Technology, Lublin; m.cholewa@pollub.pl, ORCID: 0000-0001-8457-472X \\ * Correspondence author
}

Purpose: The objective of the study was to identify factors determining the pursuit of cooperation between universities and enterprises, and to evaluate the significance of the cooperation in the regional context.

Design/methodology/approach: Empirical studies were conducted in 2019 by means of a case study method. The review of literature and available documentation enabled an interview questionnaire to be developed. Individual interviews were conducted in May 2019 with several people responsible for university-business cooperation in Lublin region.

Findings: The results of the study indicated a significant impact of university-business cooperation upon the development of the region.

Originality/value: The subject matter of the present paper pertains to university-business cooperation in Lublin region. The region is relatively low on industrialization. However, due to several universities and colleges located in the region, strong academic potential is available.

Keywords: university-business cooperation, universities, clusters, Lublin region, Lublin.

Category of the paper: Research paper, case study.

\section{Introduction}

In order to be successful on the competitive and volatile market, modern organizations must exhibit skills in establishing and maintaining relations with their surrounding environment. Only in this way the achievement of a lasting competitive advantage is possible. The subject matter of the present paper pertains to a specific form of cooperation, one established between universities and entrepreneurs.

The objective of the study was to identify factors determining the pursuit of cooperation between universities and enterprises, and to evaluate the significance of the cooperation in the regional context. Lublin region became the object of the study. The region abounds in natural resources, has considerable social potential, but is low on industrialization. The present study 
attempts to evaluate the impact of university-business cooperation upon the development of the region.

\section{University-business cooperation in the literature of the subject}

The literature of the subject offers several classifications of university-business cooperation (Mihailovich et al., 2017; Turek, 2015; Adamik, Zakrzewska-Bielawska, 2013; Zhang, Li, 2017). The division of the cooperation into individual and institutional forms is noteworthy from the university and business perspectives. Authors (Bryła, 2014; Pavlin, 2016) distinguish the following four types of cooperation:

1. Institutional forms on the part of both universities and enterprises (cooperation agreements, research consortia and research projects, research commissioned by companies and delivered by universities);

2. Institutional cooperation on the part of companies, and individual on the part of universities (student and doctoral student internships, advisory services for enterprises, employment of researchers in companies);

3. Institutional cooperation on the part of universities, and individual on the part of enterprises (visiting professors, research internships of company employees, membership of business representatives in scientific councils of universities, additional employment of company employees at universities);

4. Individual forms on the part of both actors (personal contacts, participation in conferences, joint publications and projects).

Several models of university-business cooperation are available in the literature and business practice. They differ with regard to the initiator of the relation. The cooperation may be initiated by the university or researchers who seek entities interested in financing their research ideas. The enterprise which seeks researchers interested in obtaining financing for the ideas to be commercialized may also initiate the relationship. Finally, a trilateral model (university-intermediary-enterprise) exists. The model features a mediating institution/entity. The intermediary seeks out sponsors for research and supports joint undertakings (Kłóska, Wróblewska-Jachna, 2010; Bryła, 2014). The role may be performed by e.g. local government at the level of a city, commune or region.

Clusters are a noteworthy form of institutional cooperation which enables universitybusiness cooperation. The concept of a cluster is based upon a premise that organizations operating in full isolation from other entities are non-existent. As a consequence, all organizations enter in formal/informal relations with other organizations in horizontal and vertical (e.g. in supply chain) setups (Brodzicki, Kuczewska, 2012). The intensity of the relations in specialized sectors offers the basis for cluster cooperation. At present, the literature 
features several definitions of a cluster. The following concepts can be enumerated: clusteragglomeration with a significant role of administration, cluster as an industrial complex, clustersocial network, and cluster of knowledge and innovation (Knop, 2013). The definition of a cluster by L. Knop is noteworthy. She defines a cluster as "a group of entities originating from various environments: business, science, self-government, and civil society, which consciously operates in a particular ecosystem, is focused upon a specific territory and/or around particular specialization, and which obtains synergy in the course of formal and informal relations developed owing to the potential and social capital of the cluster (...)" (Knop, 2013). The aforementioned definition clearly indicates the existence of a third party (apart from universities and businesses), i.e. local and/or regional government. Therefore, clusters realize the trilateral cooperation model, i.e. the triple helix (Etzkowitz, Zhou, 2017; Bojar, 2011; Główka, 2018).

\section{Research methodology}

The objective of the present study was to identify factors determining the pursuit of cooperation between universities and enterprises, and to evaluate the significance of the cooperation in the regional context. Lublin region became the object of the study. The region is relatively low on industrialization. However, due to several universities and colleges located in the region, strong academic potential is available.

Empirical studies were conducted in 2019 in Lublin by means of the case study method. The review of literature and available documentation enabled the interview questionnaire and the following research questions to be developed:

1. What models and forms of cooperation are delivered in Lublin region?

2. Which factors affect the initiation of cooperation between universities and enterprises?

3. What is the role of local government institutions in the development of the cooperation?

4. What is the impact of university-business cooperation upon the development of the region?

Individual interviews were conducted in May 2019. The following four people responsible for such cooperation were interviewed: the Head of Strategy and Entrepreneurship Department of Lublin City Office, the person responsible for university-business cooperation in the Marshal Office of the Lublin Voivodeship, as well as heads of technology transfer centres of two state universities in Lublin:

- Centre for Knowledge and Technology Transfer of Maria Curie Sklodowska University;

- Centre for Innovation and Technology Transfer of Lublin University of Technology. 


\section{University-business cooperation in Lublin region}

Lublin Voivodeship belongs to the least urbanized and developed regions of Poland and the European Union. It is largely a consequence of the region's economic structure and predominant low-efficiency agriculture and dominance of small and medium-sized enterprises (SMEs) (Sagan, 2016). In recent years, local governments of the region and the city of Lublin have undertaken several initiatives aiming to enhance the region's innovation by the exploitation of positive internal factors which offer development opportunities. The factors include natural resources, especially energy resources and landscape, factors stimulating the development of agriculture and several branches of industry (Kawałko, Sagan, 2014). Social, cultural and university potentials constitute a vital development stimulus for the region. The potential is manifested in e.g. a considerable number of universities and colleges, and high percentage of university-educated inhabitants (among Polish cities, Lublin is superseded only by Warsaw in this respect). These factors are reflected in program documents, including the Lublin Voivodeship Development Strategy for 2014-2020 (with the perspective to 2030). As a critical objective, Lublin Voivodeship pursues to increase knowledge and technological potential and boost entrepreneurship and innovation (Strategia, 2013). The cooperation of universities with businesses gains significance in such a context. The cooperation may result in the growth of innovation, and development of all actors involved in it as well as the whole region.

\subsection{Models and forms of cooperation in the region}

In order to establish answers to the research questions, people involved in universitybusiness cooperation in Lublin region were queried. The analysis of respondents' answers indicated that the region pursues all three cooperation models, i.e. cooperation initiated by universities, by enterprises, and one delivered in the course of the mediation of a third party, which acts as a facilitator of the cooperation.

Respondents' answers with regard to the most frequently pursued cooperation forms varied due to the multitude of forms and specific character of organizations. According to the representatives of universities, university-business cooperation is most frequently established on the initiative of enterprises (valid for $70 \%$ of formalized agreements). Sometimes, when enterprises seek to acquire external funding for innovation implementation, they are obliged to establish such cooperation by the requirements of the call they are applying under. In the remaining cases, the cooperation is established on the initiative of universities, their faculty members in particular. People with research ideas seek sponsorship among enterprises in order to bring laboratory-developed ideas to life. 
The situation is much different when viewed from the perspective of the City Office and Marshal Office. Their representatives usually work in the framework of the trilateral model where the office acts as an intermediary between the university and enterprise.

The triple helix model is employed in this mode. Joint cooperation ensures knowledge and information transfer and results in the implementation of innovation as a result of the cooperation. The triple helix model in Lublin region is usually applied to the region's priority sectors. This type of cooperation frequently translates into the direct cooperation between researchers and entrepreneurs.

According to information available on Lublin Voivodeship's webpage (www.invest.lubelskie.pl), 19 clusters operated in the region in 2018. Their sectors of focus were chiefly associated with the region's diagnosed intelligent specializations.

When queried about the forms of cooperation, respondents agreed that the region pursues various forms of cooperation, both institutional and individual in character. Due to a significant academic potential in the region, several entrepreneurs cooperate with researchers in research consortia and execute joint projects. In addition, graduation theses and doctoral dissertations are compiled on the commission of industry or based upon experiences emerging from the cooperation. The majority of courses at universities in the region offer student internships. Moreover, doctoral students and researchers complete internships in companies and consult for them. Representatives of enterprises sit on university councils and teach classes. In addition, sponsored programs are offered (specific education for a particular employer). Such cooperation is extremely effective, especially with regard to high technologies, or positions requiring proficiency in foreign languages.

\subsection{Determinants of cooperation}

The objective of the current study was to identify factors determining the pursuit of university-business cooperation in Lublin region. When queried about the determinants of the cooperation, respondents indicated the impact of both external and internal factors, which are dependent upon the involvement of individuals. Among the external factors, respondents believed that the chief importance ought to be placed upon the opportunity for obtaining external financing for the implementation of innovative projects, especially funds offered by the EU or the National Centre for Research and Development.

According to respondents, a further external factor is the city's and region's ecosystem, which in comparison with the whole country is characterized by considerable openness and strong focus on this type of cooperation. It is clearly visible in the triple helix model (e.g. in clusters operating in the region). According to the representative of the Marshal Office of Lublin, a cluster must be interested in pursuing cooperation with the local government. Only then support from administration in the soft form can be obtained, e.g. in the framework of trainings, consulting, joint delivery of projects, etc. 
Respondents believe that with regard to the determinants of cooperation in the context of clusters' operations, financial support is clearly a cluster-developing factor. However, due to formal and legal requirements ${ }^{1}$, the Marshal Office cannot finance clusters in the 2014-2020 financing perspective. This does not denote a shortage of financial support for entrepreneurs associated in clusters because they can apply for financial aid for a specific entity-partner (e.g. for innovations, development, modernization, etc. ${ }^{2}$. The representative of the Marshal Office indicated that there exists financial support on the national level. Polish Development Investments allocated financial resources for clusters. However, the resources can be consumed only for their internationalization. In addition, the funds are available exclusively to certified clusters, i.e. those holding the title of a Key National Cluster. At present, three out of twenty clusters in Lublin region hold the title ${ }^{3}$. The significance of clusters for the development of regions is acknowledged in the activity of a work group for national-level cluster policy. Apart from structural funds, the prospective financing perspective will offer cluster support from national resources.

Respondents indicated several internal factors facilitating the establishment of universitybusiness cooperation. The following can be enumerated in the context:

- Joint interests on the part of researchers and entrepreneurs;

- Mutual understanding of the specific character of the partner institution, organizational culture and institutional requirements;

- Previous contacts between researchers and entrepreneurs, previous experience in cooperation;

- Prospective benefits for the involved parties;

- Activity on the part of universities (e.g. knowledge, innovation and technology transfer centres).

\subsection{Role of local government in the cooperation}

Respondents were also requested to indicate the role of local government institutions (at region and city level) in supporting university-business cooperation. These institutions perform as an intermediary in initiating contacts between universities and enterprises by coordinating the business ecosystem (especially with regard to the city and commune of Lublin), networking various entities and acting as a catalyst for cooperation between investors (especially external ones) and universities. Frequently, the activity of the local government ceases when a relationship is established and partners start delivering joint projects independently with no role of the city or regional administration in these. According to the Head

\footnotetext{
${ }^{1}$ There is no possibility to finance clusters within the framework of the Regional Operational Program of the Lubelskie Voivodeship.

2 The entrepreneurs from the Lublin region can apply for financial support in the framework of projects implemented through the Lublin Agency for the Support of Entrepreneurship (LAWP)

${ }^{3}$ Eastern ICT Cluster, Cluster of Waste Management and Recycling, and Metalworking Cluster.
} 
of Strategy and Entrepreneurship Department of Lublin City Office, investors who were signposted by city officials to a specific university act independently from the city.

The situation is different in case of clusters in which the city administration is a partner. An example of such a cluster is Clusters3 which Lublin Voivodeship is a member of (along with partners from Italy, Spain, Latvia, Hungary, Ireland and Great Britain). The project diagnosed cluster operations and clusters' needs. Representatives of clusters were engaged in public consultations. The remaining cluster support offered by the representatives of the region include: informing on financing opportunities and calls in the framework of the Regional Operational Programme, co-organization and participation in fairs and research conferences, and establishment of contacts with potential cluster partners.

\subsection{Impact of university-business cooperation upon the development of the region}

University-business cooperation contributes to the development of the region, enhances its innovativeness, and boosts economic and social development. Respondents considered the following as positive outcomes of the cooperation:

- number of cluster initiatives in the region;

- growth of jobs and decline of unemployment;

- investment climate in the region viewed as positive by external investors;

- growing number of investment and research projects delivered by Lublin enterprises in cooperation with researchers;

- commercialization of research results;

- infrastructural and social investments in the development of Lublin universities (new courses in response to the needs of economy, growing internationalization of universities, etc.);

- swift economic development of the region;

- improvement of the quality of life.

According to respondents, the outcomes of the cooperation are long-term and pertain to each involved party, i.e. universities, enterprises, local governments, and inhabitants of the region who benefit from the outcomes. The region's potential for development was recognized by "Indeks Millennium 2018-Potencjał Innowacyjności Regionów” ranking. Lublin region ranked $5^{\text {th }}$ and superseded more industrialized regions in Poland. The ranking evaluated 5 criteria, which according to experts exert the strongest impact upon the development of innovation ${ }^{4}$. Lublin region is among the regions which, since 2010, have made the greatest leap in the development of innovation potential (Maliszewski et al., 2018).

\footnotetext{
${ }^{4}$ Work efficiency, value added rate, research and development expenditures, post-secondary education, the number of people working in the R \& D area and the number of patents granted were taken into account.
} 


\section{Conclusions}

The analysis of results of the study indicated several determinants of university-business cooperation in Lublin region. Various forms and models of cooperation are pursued. Usually it is entrepreneurs who initiate the cooperation.

University-business cooperation results in numerous benefits for all parties involved, as well as for Lublin region and its inhabitants in a broader context. The benefits can be viewed in several aspects - political, market, R\&D, and social. Respondents highlighted the impact of cooperation upon the region in light of enterprise development, access to information and resources, and joint cooperation of diversified entities. This is of special significance for Lublin region dominated by small enterprises, which, due to the character of the local market (relatively low income, relatively low number of inhabitants in relation to the territory) often poses a barrier for development.

Respondents emphasize that university-business cooperation in Lublin region functions on several different levels. Long-term joint projects are delivered. These result in the implementation of research results in business practice. However, there exist numerous examples of cooperation which has just been established. This may be seen in clusters, whose majority are only beginning to emerge, i.e. cluster members are analysing cooperation opportunities and potential benefits. Frequently, clusters lack formalized structure and management maturity.

It is noteworthy that despite difficulties in the cooperation, Lublin region has been effectively exploiting academic potential and consolidating human capital. Experts highlight high innovation activity of the region (Maliszewski et al., 2018), which undeniably translates into university-business cooperation.

\section{References}

1. Adamik, A., and Zakrzewska-Bielawska, A. (2013). Organizacja w sieciach współpracyod prostych do złożonych form współpracy międzyorganizacyjnej. In: A. Adamik (Ed.), Nauka o organizacji. Ujęcie dynamiczne. Warszawa: Oficyna Wydawnicza a Wolters Kluwers, 440-473.

2. Bojar, M. (2011). Współpraca wewnątrzregionalna jako czynnik rozwoju regionalnego doświadczenia z procesu klasteringu, In: R. Borowiecki, T. Rojek (Eds.), Procesy formowania więzi organizacyjnych we wspótczesnej gospodarce. Kraków: Prace Uniwersytetu Ekonomicznego w Krakowie, 266. 
3. Brodzicki, T., and Kuczewska, J. (2012). Klastry i polityka klastrowa w Polsce. Konkurencyjność przedsiębiorstw, sektorów i regionów. Gdańsk: Wydawnictwo Uniwersytetu Gdańskiego.

4. Bryła, P. (2014). Możliwości współpracy polskich uczelni wyższych ze sferą biznesu (Co-operation Possibilities between Polish Universities and Business). Studia Edukacyjne, (31), 95-112.

5. Etzkowitz, H., \& Zhou, C. (2017). The triple helix: University-industry-government innovation and entrepreneurship. UK: Routledge.

6. Główka, C. (2018). Znaczenie organizacji klastrowej dla środowiska potrójnej helisy. Warszawa: Difin.

7. http://www.invest.lubelskie.pl/pl/klastry, 25.05.2019.

8. https://mapaklastrow.parp.gov.pl/Klastry2/index.html, 25.05.2019.

9. https://www.gov.pl/web/przedsiebiorczosc-technologia/lista-kkk, 28.05.2019.

10. https://www.interregeurope.eu/clusters3/, 28.05.2019.

11. Kawałko, B., and Sagan, M. (2014). Strategia rozwoju województwa lubelskiego na lata 2014-2020. Kontekst Lublina metropolitalnego. In: M. Sagan, K. Żuk (Eds.), Lublin 2020. Cztery oblicza przyszłości miasta. Lublin: Wydawnictwo UMCS, 549-557.

12. Kłóska, I., and Wróblewska-Jachna, J. (2010). Możliwości współpracy pomiędzy nauką a biznesem. Doświadczenia, oczekiwania, bariery w opinii przedsiębiorców, In: J. Matuszek and M. Baron-Puda (Eds.), Szanse i bariery wspótpracy nauki i biznesu IT w podregionie bielskim. Bielsko-Biała: Fundacja Centrum Nowych Technologii, 40-41.

13. Knop, L. (2013). Zarzadzanie klastrem - koncepcje, strategie, modele. Gliwice: Wydawnictwo Politechniki Śląskiej.

14. Maliszewski, G., Berent, A., Buczek, Ł., Pulnar, A. (2018). Indeks Millennium - potencjat innowacyjności regionów 2018. Warszawa: Millenium Bank. Retrieved from https://www.bankmillennium.pl/documents/10184/26648072/Indeks_Millennium_2018Potencjal_Innowacyjnosci_Regionow.pdf, 04.06.2019.

15. Mihailovich, N.S., Pakhomova, E.A., Goosen, E.V., \& Rozhkova, O.V. (2017, June). Forms of cooperation of government, business and science to create innovative sectors of economy (regional aspect). International Conference on Trends of Technologies and Innovations in Economic and Social Studies 2017. Paris: Atlantis Press.

16. Pavlin, S. (2016). Considering university-business cooperation modes from the perspective of enterprises. European Journal of Education, 51(1), 25-39.

17. Sagan, M. (2016). Instytucje samorządowe jako źródło międzynarodowej konkurencyjności polskich przedsiębiorstw. Przykład województwa lubelskiego i Lublina. In: M. Poniatowska-Jaksch, R. Sobiecki (Eds.), Konkurencyjność przedsiębiorstw-aspekty międzynarodowe i sektorowe. Warszawa: Oficyna Wydawnicza Szkoła Główna Handlowa, 111-131. 
18. Strategia Rozwoju Województwa Lubelskiego na lata 2014-2020 (z perspektywa do 2030) (2013). Lublin: Urząd Marszałkowski Województwa Lubelskiego. Retrieved from http://strategia.lubelskie.pl/SRWL\%202014-2020\%20FIN.pdf, 01.06.2019.

19. Turek, I. (2015). Współpraca między organizacjami w zarządzaniu pracami badawczorozwojowymi. Studia Ekonomiczne, 225, 213-221.

20. Zhang, L., and Li, H. (2017). Selection Between One-Time Transfer and UniversityIndustry Cooperation in Technology Transfer: A Matching Model. International Journal of Economics, Finance and Management Sciences, 5(5), 235. 